\title{
Emotional Intelligence and Transformational Leadership Style Empirical Research on Public Schools in Jordan
}

\begin{abstract}
Mohammad Hunitie
Correspondence: Mohammad Hunitie, Department of Public Administration, Faculty of Economics and Administration, King Abdulaziz University, Saudi Arabia. E-mail: mohammadhunitie@live.com
\end{abstract}

Received: June 19, 2016

doi:10.5539/ibr.v9n9p168

\author{
Accepted: July 5, 2016 \\ Online Published: August 17, 2016 \\ URL: http://dx.doi.org/10.5539/ibr.v9n9p168
}

\begin{abstract}
The aim of this study is to investigate the relationship between emotional intelligence (EI) and transformational leadership (TL) style in public schools in Amman, Jordan. A sample consisting of 250 teachers was randomly selected to collect data on their managers' EI competencies, which are self-awareness (SEA), self-management (SEM), social awareness (SOA), and relationship management (REM), and their TL behaviours using a questionnaire developed based on the literature for the purpose of the current study. All the questionnaires were returned completed and valid for statistical analysis. Four hypotheses were put forward by the study, in which EI was postulated to exert an impact on four dimensions of TL style, namely idealized influence (IDI), inspirational motivation (INM), intellectual stimulation (INS), and individualized consideration (INC). The study deduced a significant and positive effect of EI on all the dimensions of TL. A key contribution of this study is the finding that leaders need not only competencies to transform their subordinates but also a sense of emotional intelligence. Following these results, the implications of the study were derived. One of the most important recommendations indicated that managers have to be trained to acquire emotional intelligence skills.
\end{abstract}

Keywords: emotional intelligence, transformational leadership, schools

\section{Introduction}

EI as a set of competencies enhances the skills of leaders directed toward developing and motivating employees to achieve the organization's vision (Antonakis et al., 2009). TL, on the other hand, as a set of leaders' characteristics, aims to influence employees' behaviours for the sake of achieving the organization's objectives (Lam \& O'Higgins, 2013). Hence, both EI and TL are necessary to attain objectives. Researchers have defined EI in terms of numerous dimensions. The most common dimensions focus on SEA, SEM, SOA, and REM (Christie et al., 2015; Gardner \& Stough, 2002; Hess \& Bacigalupo, 2011; Hopkins et al., 2007; Kerr et al., 2006; Riggio \& Reichard, 2008; Sharma, 2012). SEA is related to emotional self-awareness (E-SEA) and accurate self-assessment (A-SEA). SOA belongs to empathy (EMP), service orientation (SEO), and organizational awareness (ORA). SEM is connected with trustworthiness (TRT), conscientiousness (CON), adaptability (ADA), achievement drive (ACD), and initiative (INI). Finally, REM concerns communication (COM), developing others (DEO), influence (INF), leadership (LDR), conflict management (COM), change catalysts (CHCs), building bonds and teamwork (BBT), and collaboration (COL) (Gardner \& Stough, 2002; Hess \& Bacigalupo, 2011; Hopkins et al., 2007; Sharma, 2012). Researchers have also defined TL with regard to leaders' characteristics as representing their abilities to disseminate the organization's vision, develop their followers' abilities, and motivate their followers to act in favour of group interests (Mandell \& Pherwani, 2003). The most common dimensions used for TL are IDI, INM, INS, and INC. Many studies have been conducted to investigate the relationship between EI and TL. Some studies have indicated that EI is significantly and positively related to TL (Lam \& O’Higgins, 2013; Leban \& Zulauf, 2004; Stanescui \& Cicei, 2012; Tsai et al., 2011). Conversely, other studies have found no significant relationship between EI and TL (Genderen, 2012; Jayakody \& Gamage, 2015). Therefore, the aim of this study was to explore the relationship between EI (SEA, SEM, SOA, and REM) and TL (IDI, INM, INS, and INC) in an educational setting from the Arab world, specifically Jordan, using a sample selected from public schools in Amman. The study was conducted in 2016 from teachers' perspectives using a reliable and valid questionnaire that was developed based on previous studies and related works. The main contribution to the body of knowledge can be found in the investigation of the relationship between EI and $\mathrm{TL}$ in the educational domain. This introduction is followed by a literature review and hypothesis development, in which both EI and TL are defined and conceptualized. The relationships between these two constructs are also 
discussed, and the study's model is presented. Section three provides the study's methodology. It comprises two main parts: the study sample and measurements. Section four, entitled data analysis and results, consists of the study's reliability and validity, a correlation matrix as well as hypothesis testing. Section five contains a discussion of the results and the conclusion. Finally, the research implications and directions for future studies are presented in section six.

\section{Literature Review and Hypothesis Development}

\subsection{Emotional Intelligence Definition and Dimensions}

Hess and Bacigalupo (2011) cited three models on which researchers can rely to understand the term emotional intelligence. According to them, these models encompass how individuals approach different emotional conditions and how they adapt to these conditions; how individuals use their behaviours in self-assessment; and how individuals invest their emotions to enhance their performance on the basis of their abilities and skills. Hoffman and Frost (2006) defined EI in terms of three dimensions: awareness, understanding, and controlling one's own and others' emotions. For them, these dimensions involve abilities to recognize self-emotions with others' emotions and needs, competencies to understand emotional indications, utilizing emotions to expedite activities, and working with one's own and others' emotions and empathy. In their 2011 work, Hess and Bacigalupo outlined four dimensions of EI with more than sixteen characteristics. Barling et al. (2000) used five dimensions to describe emotional intelligence: understanding one's own and others' emotions, controlling one's emotions, managing one's own as well as others' emotions, and managing relationships. They adopted five dimensions of EI from Bar-On's (1997) self-report emotional intelligence inventory: stress management, adaptability, interpersonal, intrapersonal, and mood. Palmer et al. (2001) applied items from the Trait Meta Mood Scale developed by Salovey et al. (1995) to gauge emotional intelligence with regard to individuals' ability to be aware of their own and others' emotions besides the ability to manage these emotions. Gardner and Stough (2002) pointed out that researchers have conceptualized emotional intelligence using three main models, namely the ability model developed by Mayer and Salovey (1997), the competency model introduced by Bar-On (1997), and the non-cognitive model established by Goleman (2001). In their study on the relationship between leadership and emotional intelligence, Gardner and Stough (2002) used the Swinburne University Emotional Intelligence Test (SUEIT) developed by Palmer and Stough (2001), which consists of five dimensions, explicitly direct cognition of emotions, emotional recognition and expression, understanding of external emotions, control of emotions, and management. Downey et al. (2006) employed the same test (SUEIT) to measure emotional intelligence in female managers in Australia. Kerr et al. (2006) employed the Mayer-Salovey-Caruso Emotional Intelligence Test (MSCEIT) developed by Mayer et al. (2000) to measure the total level of emotional intelligence and abilities of individuals in four areas, specifically perceiving, understanding, using, and managing emotions. Stein et al. (2009) measured emotional intelligence using the Emotional Quotient Inventory developed by Bar-On (1997). Table 1 shows the dimensions and measures of emotional intelligence used in the literature. 
Table 1. Dimensions and measures of emotional intelligence used in the literature

\begin{tabular}{|c|c|}
\hline Dimensions & Reference (s) \\
\hline Self-awareness: emotional self-awareness and accurate self-assessment. & Gardner and Stough (2002) \\
\hline $\begin{array}{l}\text { Social-awareness: empathy, service orientation, and organizational } \\
\text { awareness. }\end{array}$ & $\begin{array}{l}\text { Hopkins et al. (2007) } \\
\text { Hess and Bacigalupo (2011) }\end{array}$ \\
\hline $\begin{array}{l}\text { Self-management: trustworthiness, conscientiousness, adaptability, } \\
\text { achievement drive, and initiative. }\end{array}$ & Sharma (2012) \\
\hline \multicolumn{2}{|l|}{$\begin{array}{l}\text { Relationship management: developing others, influence, communication, } \\
\text { conflict management, leadership, change catalyst, building bonds and } \\
\text { teamwork, and collaboration. }\end{array}$} \\
\hline Conscientiousness, empathy, coaching, and sensitivity. & Hoffman and Frost (2006) \\
\hline $\begin{array}{l}\text { The Swinburne University Emotional Intelligence Test (SUEIT) by Palmer } \\
\text { and Stough (2001): emotional recognition and expression, emotions direct } \\
\text { cognition, understanding of external emotions, emotions control and } \\
\text { management. }\end{array}$ & Gardner and Stough (2002) \\
\hline The Mayer-Salovey-Caruso emotional intelligence test (MSCEIT) by Mayer & Kerr et al. (2006) \\
\hline $\begin{array}{l}\text { et al. (2000): perceiving or identifying emotions, understanding emotions, } \\
\text { using emotions to enhance thinking, and managing emotions }\end{array}$ & Riggio and Reichard (2008) \\
\hline The Emotional Quotient Inventory developed by Bar-On (1997): stress & Barling et al. (2000) \\
\hline management, general mood, adaptability, and interpersonal and intrapersonal & Stein et al. (2009) \\
\hline competencies. & Erkutlu and Chafra (2012) \\
\hline The Emotional Intelligence (EI) Questionnaire by Higgs and Dulewicz & Dulewicz et al. (2003) \\
\hline (1999): self-awareness, emotional resilience, motivation, interpersonal & Higgs and Aitken (2003) \\
\hline sensitivity, influence (leadership), intuitiveness, conscientiousness. & Dulewicz and Higgs (2003) \\
\hline $\begin{array}{l}\text { The Emotional Skills Assessment Process (ESAP) by Nelson and Low } \\
\text { (2003): self-esteem, assertion, social awareness (comfort), empathy, decision } \\
\text { making, influence, goal setting (drive strength), personal responsibility } \\
\text { (ethical commitment), time management, and stress management. }\end{array}$ & Tang et al. (2010) \\
\hline $\begin{array}{l}\text { The EQ Index (EQI) by Rahim et al. (2002, 2006): self-awareness, } \\
\text { self-regulation, social skills, empathy, motivation. }\end{array}$ & Polychroniou (2009) \\
\hline $\begin{array}{l}\text { The Emotional Intelligence Scale (EIS-41) by Schutte et al. (1998): mood } \\
\text { regulation, utilization of emotions, and appraisal of emotions. }\end{array}$ & Mohamed et al. (2012) \\
\hline
\end{tabular}

\subsection{Transformational Leadership Definition and Dimensions}

Based on Bass and Avolio (1994), Mandell and Pherwani (2003) defined TL in terms of three characteristics: a leader's ability to disseminate the organization's vision, a leader's competency to develop his or her followers' abilities, and a leader's ability to motivate his or her followers to act in favour of group interests. According to Lam and O'Higgins (2013), TL can be defined based on leaders' ability to influence the behaviours of employees for the purpose of achieving the organization's objectives. As regards the dimensions of TL, Bass and Avolio's leadership model consists of five components, namely attributed idealized influence, behavioural idealized influence, inspirational motivation, intellectual stimulation, and individualized consideration. The model has been adopted by many researchers, for example Lam and O'Higgins (2013) and Stanescui and Cicei (2012). Table 2 presents the dimensions of transformational leadership used in the literature.

Table 2. Dimensions of transformational leadership used in the literature

\begin{tabular}{|c|c|}
\hline Dimensions & Reference (s) \\
\hline $\begin{array}{l}\text { Idealized influence (attributed and behavioral), inspirational motivation, } \\
\text { intellectual stimulation, and individualized consideration. }\end{array}$ & $\begin{array}{l}\text { Leban and Zulauf (2004) } \\
\text { Stanescui and Cicei (2012) } \\
\text { Shahhosseini et al. (2013) } \\
\text { Lam and O'Higgins (2013) } \\
\text { Arunima et al. (2014) } \\
\text { Bratton et al. (2011) }\end{array}$ \\
\hline
\end{tabular}

\subsection{Relationship between Emotional Intelligence and Transformational Leadership}

Both EI and TL are critical for organizations' success. Lam and O'Higgins (2013), based on a work conducted by Kupers and Weibler (2006), summarized the importance of EI in the context of TL. According to them, self-confidence and control, empathy, influence, organizational awareness, visionary leadership, and change catalysts affect the first dimension of transformational leadership, which is idealized influence. Secondly, achievement drive, initiative, empathy, developing others, communication, conflict management, and building bonds influence inspirational motivation. Thirdly, initiative, empathy, developing others, and change catalysts have an impact on intellectual stimulation. Finally, adaptability, empathy, communication, developing others, and conflict management affect individual consideration. In terms of related works, numerous researchers have studied the relationship between EI and TL style. Leban and Zulauf (2004) investigated the relationship between 
EI and TL using a sample encompassing 24 project managers from different industries. Their results allowed them to accept the hypothesis that EI is significantly related to transformational leadership, which in turn improves project performance. Particularly, there is a significant relationship between understanding emotions and inspirational motivation as well as between using emotions and idealized influence and individual consideration. Using a sample consisting of 101 managers from Romania, Stanescui and Cicei (2012) explored the relationship between EI and TL and affirmed that EI is significantly associated with TL dimensions. Lam and O'Higgins (2013) investigated the relationship between EI and leadership style (laissez-faire, transformational, and transactional leadership) in private organizations from China. Their results pointed out that EI and TL are significantly and positively associated. Contrary to these results, Genderen (2012) carried out a study on the relationship between EI and TL style in a sample involving 152 Russian managers. Their results rejected the hypothesis that EI is significantly related to TL style. Tsai et al. (2011) conducted a study on the banking industry in Taiwan, hypothesizing a positive effect of supervisors' EI on leadership style (transformational leadership and transactional leadership). Their results confirmed the hypothesized effect and indicated that leadership style, as perceived by the respondents, is related to supervisors' EI. Exploring the relationship between EI and TL in Malaysian universities, Jayakody and Gamage (2015) found that EI was not related to TL.

Based on the above-mentioned literature, the present study postulated the following hypotheses:

H01: Emotional intelligence significantly and positively affects idealized influence.

H02: Emotional intelligence significantly and positively affects individualized consideration.

H03: Emotional intelligence significantly and positively affects inspirational motivation.

H04: Emotional intelligence significantly and positively affects intellectual stimulation.

\section{Research Model}

The research model, as can be seen in figure 1, consists of the independent variable (EI) and the dependent variables (TL). The model shows four hypothesized relationships between EI and TL, that is, EI and IDI, IND, INM, and INS.

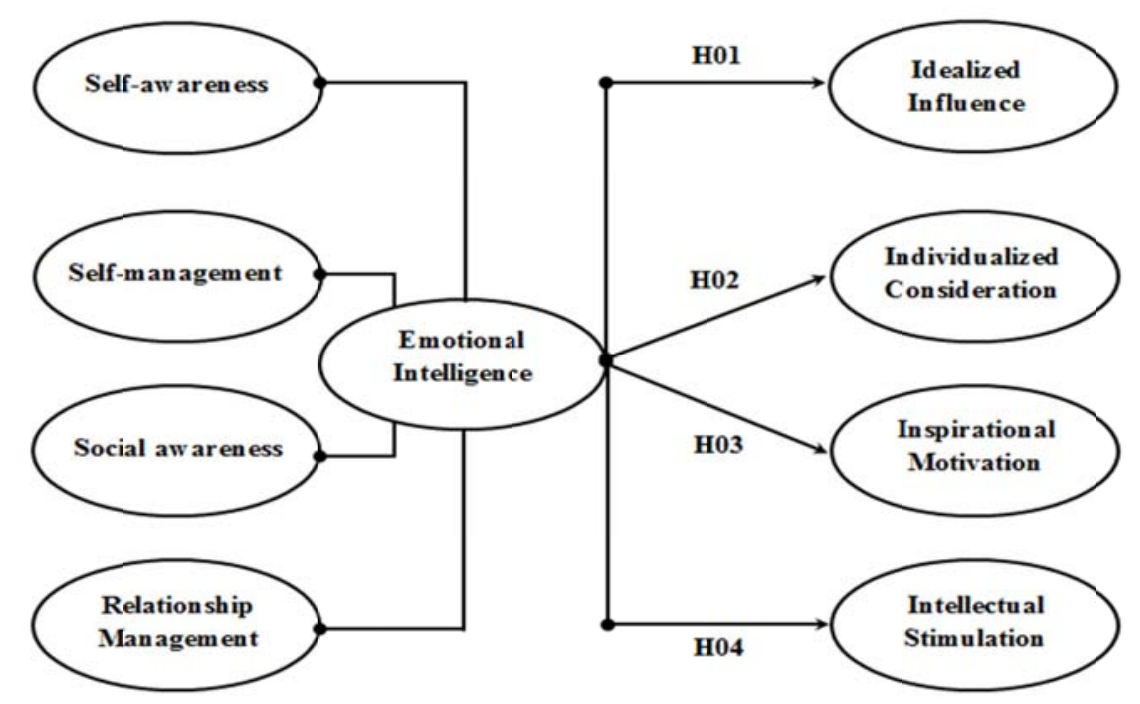

Figure 1. Study model

\section{Research Methodology}

\subsection{Research Sample}

The sample of this study comprised 250 teachers selected from 10 public schools in Amman, the capital city of Jordan. The sample involved 138 males (55.2\%) and 112 females $(44.8 \%)$, all of whom held at the minimum a bachelor's degree. Their ages ranged from 24 to 45 years, and they had an average of 5.9 years of experience.

\subsection{Measures}

Emotional intelligence was measured in the current study using four dimensions - self-awareness, self-management, social awareness, and relationship management - based on works carried out by Christie et al. (2015), Gardner and Stough (2002), Hess and Bacigalupo (2011), Hopkins et al. (2007), Kerr et al. (2006), 
Riggio and Reichard (2008), and Sharma (2012). These items cover the following sub-dimensions: E-SEA and A-SEA, EMP, SEO, ORA, TRT, CON, ADA, ACD, INI, DEO, INF, COM, COM, CHC, BBT, and COL. Transformational leadership was measured based on the Multifactor Leadership Questionnaire (MLQ) 5X-Short developed by Bass and Avolio (2000). A questionnaire using a 5-point Likert scale ranging from $1=$ strongly disagree to $5=$ strongly agree was developed to collect data from the study respondents.

\section{Data Analysis and Results}

\subsection{Reliability and Validity}

Table 3 presents the results of the reliability and validity tests of the study measurements. The results confirm that these measurements are reliable and valid $\left(\alpha=0.862\right.$ and 0.899 , chi-square $\left(\chi^{2} / \mathrm{df}\right)<2.0$, root mean square error of approximation (RMSEA) $<0.080$, and comparative fit index $(\mathrm{CFI})>0.9$ ).

Table 3. Validity and reliability

\begin{tabular}{lllllll}
\hline Construct & Items & $\alpha$ & $\chi 2 / \mathrm{df}$ & $\mathrm{RMSEA}$ & CFI & P \\
\hline Emotional intelligence & 8 & 0.862 & 1.21 & 0.058 & 0.91 & 0.000 \\
Transformational leadership & 8 & 0.899 & 1.59 & 0.067 & 0.93 & 0.000 \\
\hline 5.2 Correlation Matrix & & & &
\end{tabular}

Table 4 shows the means, standard deviations, and coefficients of the study variables. These results indicate that the EI dimensions are positively correlated with each other. The correlation coefficients range from 0.3 to 0.6. Additionally, the TL dimensions are related to each other and at the same time to the EI dimensions. The correlation coefficients range from 0.3 to 0.8 .

Table 4. Means, standard deviations, and correlations of the study variables

\begin{tabular}{|c|c|c|c|c|c|c|c|c|c|c|}
\hline & $\mathbf{M}$ & SD & 1 & 2 & 3 & 4 & 5 & 6 & 7 & 8 \\
\hline 1. SEA & 3.7 & 0.87 & - & & & & & & & \\
\hline 2. SEM & 3.8 & 0.65 & 0.3 & - & & & & & & \\
\hline 3. $\mathrm{SOA}$ & 3.9 & 0.75 & 0.5 & 0.6 & - & & & & & \\
\hline 4. REM & 3.8 & 0.72 & 0.5 & 0.6 & 0.4 & - & & & & \\
\hline 5. IDI & 3.7 & 0.79 & 0.4 & 0.5 & 0.5 & 0.4 & - & & & \\
\hline 6. INC & 3.8 & 0.95 & 0.6 & 0.7 & 0.6 & 0.8 & 0.3 & - & & \\
\hline 7. INM & 4.0 & 0.85 & 0.6 & 0.8 & 0.7 & 0.6 & 0.4 & 0.5 & - & \\
\hline 8. INS & 3.9 & 0.91 & 0.7 & 0.4 & 0.7 & 0.5 & 0.5 & 0.6 & 0.4 & - \\
\hline
\end{tabular}

\subsection{Hypothesis Testing}

The four hypotheses of the present study supposed that EI, as measured by SEA, SEM, SOA, and REM, is positively related to each dimension of TL, which are idealized influence, INM, INS, and INC. As can be seen in table 5, hypothesis 1 was supported $\left(\mathrm{R}^{2}=0.331, \beta=0.321, \mathrm{t}=5.113, \mathrm{P}=0.001\right)$, and hypothesis 2 was also supported $\left(\mathrm{R}^{2}=\right.$ $0.261, \beta=0.220, t=4.851, P=0.000)$. On the other hand, hypothesis 3 was accepted $\left(R^{2}=0.240, \beta=0.234, t=4.110\right.$, $\mathrm{P}=0.001)$. Finally, hypothesis 4 was accepted $\left(\mathrm{R}^{2}=0.311, \beta=0.281, \mathrm{t}=4.521, \mathrm{P}=0.000\right)$.

Table 5. Results of the hypothesis testing

\begin{tabular}{llllll}
\hline Hypotheses & $\mathbf{R}^{2}$ & $\boldsymbol{\beta}$ & $\mathbf{t}$ & $\mathbf{P}$ & Result \\
\hline H01 & 0.331 & 0.321 & 5.113 & 0.001 & Supported \\
H02 & 0.261 & 0.220 & 4.851 & 0.000 & Supported \\
H03 & 0.240 & 0.234 & 4.110 & 0.001 & Supported \\
H04 & 0.311 & 0.281 & 4.521 & 0.000 & Supported \\
P $\leq 0.05$ & & & & & \\
\hline
\end{tabular}

\section{Discussion and Conclusion}

This study explored the relationship between EI and TL style in public schools in Amman, the capital city of Jordan. EI was measured based on four dimensions: SEA, SEM, SOA, and REM. TL was also assessed based on four dimensions: IDI, INM, INS, and INC. The results revealed that EI is positively related to IDI. Equally, the results indicated that EI significantly affects INC. As regards the relationship between EI and INM, the hypothesis was accepted. Finally, the findings found a positive effect of EI on INS. Figure 2 displays the results of this study. 


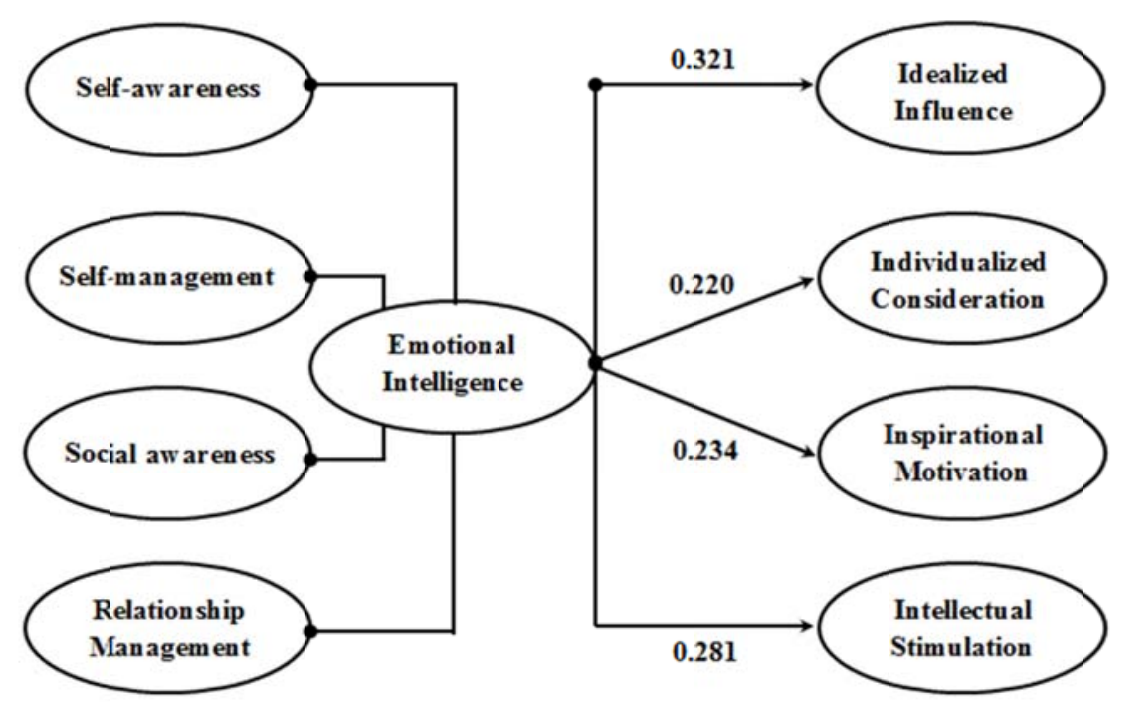

Figure 2. Final model of the study

Similar results have been reported in the literature. Arunima et al. (2014) found a moderate impact of EI on the

TL style of healthcare professionals in India. Barling et al. (2000) pointed out that the variance in three dimensions of TL (IDI, INM, and INC) is explained by EI. Downey et al. (2006) concluded that there is a significant relationship between EI and TL behaviour among female managers possessing EI competencies.

Gardner and Stough (2002) revealed a high correlation between EI and TL of high-level managers. In their study on the relationship between EI and TL style of Russian managers, Genderen (2012) found no significant relationship between these variables. Tsai et al. (2011), in a study on the banking industry in Taiwan, accepted the positive effect of supervisors' EI on TL and transactional leadership style.

\section{Implications and Future Research}

The current study supported the positive impact of EI on TL in an educational setting. Hence, the main contribution of this study is related to teachers' perspectives on the relationship between principals' EI and their TL, from which one can conclude that EI is a critical antecedent of leadership style success. In relation to study limitations, Barling et al. (2000) argued that the sample size has the main effects on the results of a study with respect to their generalizability and conclusion validity. Hence, a larger sample size should be considered in future research. The study is limited to public schools in Amman; a larger sample of private and public schools from other regions in Jordan can be used to gain a wider insight into the effect of EI on TL. Finally, other leadership styles should be considered in future research.

\section{References}

Antonakis, J., Ashkanasy, N., \& Dasborough, M. (2009). Does leadership need emotional intelligence? The Leadership Quarterly, 20(2), 247-261. http://dx.doi.org/10.1016/j.leaqua.2009.01.006

Arunima, S., Ajeya, J., Sengupta, K., Mariamma, P., \& Tripathi, K. (2014). Comparison of transformational leadership and its different attributes of leadership with emotional intelligence in Indian healthcare: An empirical aspect. Advances in Management, 7(10), 37-45.

Barling, J., Slater, F., \& Kelloway, E. (2000). Transformational leadership and emotional intelligence: an exploratory study. Leadership \& Organization Development Journal, 21(3), 157-161. http://dx.doi.org/10.1108/01437730010325040

Bass, B., \& Avolio, B. (2000). MLQ: Multifactor leadership questionnaire, $2^{\text {nd }}$ edition, Technical Report. Redwood City: CA: Mind Garden.

Bratton, V., Dodd, N., \& Brown, F. (2011). The impact of emotional intelligence on accuracy of self-awareness and leadership performance. Leadership \& Organization Development Journal, 32(2), 127-149. http://dx.doi.org/10.1108/01437731111112971

Christie, A., Jordan, P., \& Troth, A. (2015). Trust antecedents: emotional intelligence and perceptions of others. International Journal of Organizational Analysis, 23(1), 89-101. http://dx.doi.org/10.1108/IJOA-07-2013-0695 
Downey, L., Papageorgiou, V., \& Stough, C. (2006). Examining the relationship between leadership, emotional intelligence and intuition in senior female managers. Leadership \& Organization Development Journal, 27(4), 250-264. http://dx.doi.org/10.1108/01437730610666019

Dulewicz, V., \& Higgs, M. (2003). Leadership at the top: The need for emotional intelligence in organizations. The International Journal of Organizational Analysis, 11(3), 193-210. http://dx.doi.org/10.1108/eb028971

Erkutlu, H., \& Chafra, J. (2012). The impact of team empowerment on proactivity. Journal of Health Organization and Management, 26(5), 560-577. http://dx.doi.org/10.1108/14777261211256918

Gardner, L., \& Stough, C. (2002). Examining the relationship between leadership and emotional intelligence in senior level managers. Leadership \& Organization Development Journal, 23(2), 68-78. http://dx.doi.org/10.1108/01437730210419198

Genderen, E. (2012). Relationship between emotional intelligence and leadership style: A comparative-gender study. Review of International Comparative Management, 13(2), 224-236.

Hess, D., \& Bacigalupo, J. D. (2011). Enhancing decisions and decision-making processes through the application of emotional intelligence skills. Management Decision, 49(5), 710-721. http://dx.doi.org/10.1108/00251741111130805

Higgs, M., \& Aitken, P. (2003). An exploration of the relationship between emotional intelligence and leadership $\begin{array}{lllll}\text { potential. Journal of } & \text { Managerial Psychology, } & \text { 18(8), }\end{array}$ http://dx.doi.org/10.1108/02683940310511890

Hoffman, B., \& Frost, B. (2006). Multiple intelligences of transformational leaders: an empirical examination", International Journal of Manpower, 27(1), 37-51. http://dx.doi.org/10.1108/01437720610652826

Hopkins, M., O'Neil, D., \& Williams, H. (2007). Emotional intelligence and board governance: leadership lessons from the public sector. Journal of Managerial Psychology, 22(7), 683-700. http://dx.doi.org/10.1108/02683940710820109

Jayakody, T., \& Gamage, P. (2015). Impact of the emotional intelligence on the transformational leadership style and leadership effectiveness: Evidence from Sri Lankan national universities. Journal of Strategic Human Resource Management, 4(1), 1-12.

Kerr, R., Garvin, J., Heaton, N., \& Boyle, E. (2006). Emotional intelligence and leadership effectiveness. Leadership \& Organization Development Journal, 27(4), 265-279. http://dx.doi.org/10.1108/01437730610666028.

Lam, C., \& O’Higgins, E. (2013). Emotional Intelligence and Leadership Styles in China. Asia Pacific Management Review, 18(4), 441-467.

Leban, W., \& Zulauf, C. (2004). Linking emotional intelligence abilities and transformational leadership styles. Leadership \& Organization Development Journal, 25(7), 554-564. http://dx.doi.org/10.1108/01437730410561440

Mandell, B., \& Pherwani, S. (2003). Relationship between emotional intelligence and transformational leadership style: A gender comparison. Journal of Business and Psychology, 17(3), 387-404. http://dx.doi.org/10.1023/A:1022816409059

Mohamed, A., El Khouly, S., \& Saad, M. (2012). Reliability and factor structure of a trait emotional intelligence measure in four Arab countries. Education, Business and Society: Contemporary Middle Eastern Issues, 5(1), 83-92. http://dx.doi.org/10.1108/17537981211225871

Palmer, B., Walls, M., Burgess, Z., \& Stough, C. (2001). Emotional intelligence and effective leadership. Leadership \& Organization Development Journal, 22(1), 5-10. http://dx.doi.org/10.1108/01437730110380174

Polychroniou, P. (2009). Relationship between emotional intelligence and transformational leadership of supervisors. Team Performance Management: An International Journal, 15(7/8), 343-356. http://dx.doi.org/10.1108/13527590911002122

Riggio, R., \& Reichard, R. (2008). The emotional and social intelligences of effective leadership. Journal of Managerial Psychology, 23(2), 169-185. http://dx.doi.org/10.1108/02683940810850808

Shahhosseini, M., Silong, A., \& Ismaill, I. (2013). Relationship between transactional, transformational leadership styles, emotional intelligence and job performance International Refereed Research Journal, 
IV(1/1), 15-22.

Sharma, R. (2012). Measuring social and emotional intelligence competencies in the Indian context. Cross Cultural Management: An International Journal, 19(1), 30-47. http://dx.doi.org/10.1108/13527601211195619

Stanescui, D., \& Cicei, C. (2012). Leadership styles and emotional intelligence of Romanian public managers: Evidences from an exploratory pilot Study. Revista De Cercetare Interventie Sociala, 38, 107-121.

Stein, S., Papadogiannis, P., Yip, J., \& Sitarenios, G. (2009). Emotional intelligence of leaders: a profile of top executives. Leadership \& Organization Development Journal, 30(1), 87-101. http://dx.doi.org/10.1108/01437730910927115

Tang, H. W., Yin, M. S., \& Nelson, D. (2010). The relationship between emotional intelligence and leadership $\begin{array}{llll}\text { practices. Journal of } & \text { 899-926. }\end{array}$ http://dx.doi.org/10.1108/02683941011089143

Tsai, M. T., Tsai, C. L., \& Wang, Y. C. (2011). A study on the relationship between leadership style, emotional intelligence, self-efficacy and organizational commitment: A case study of the Banking Industry in Taiwan. African Journal of Business Management, 5(13), 5319-5329. http://dx.doi.org/10.5897/AJBM10.932

\section{Copyrights}

Copyright for this article is retained by the author(s), with first publication rights granted to the journal.

This is an open-access article distributed under the terms and conditions of the Creative Commons Attribution license (http://creativecommons.org/licenses/by/4.0/). 